\title{
Self-Directed Learning for Learner Autonomy: Teachers' and Students' Perceptions
}

Luk Gharti

\begin{abstract}
The research entitled Self-directed Learning for Learner Autonomy: Perceptions of Teachers and Students was carried out to explore the perceptions about Self Directed Learning (SDL) for Learner Autonomy (LA) and analyze the roles of teachers to engage students in SDL. Considering the objectives, the primary data was collected from five master level English Language Teaching (ELT) teachers and three groups of master level students from Pokhara, Kaski. The purposive non-random sampling procedure was used to select the participants. The study was conducted using in-depth interview and Focused Group Discussion (FGD) tools to collect data. The obtained data from the respondents were analyzed and interpreted using analytical and interpretative procedure. It is a new approach in language teaching and learning in Nepalese context though it has been practicing since earlier. The finding shows that all the respondents have positive perceptions and its great contribution for developing LA. SDL helps learners to achieve better achievement and effective learning. It helps teachers to find the necessary changes and increases motivation to the learners to learn. But because of student's unawareness, time constraint, no inspirations of institutions, student's false assumptions, lack of insight knowledge about SDL, etc are creating the challenges in its proper application. In the study, the teachers' roles are facilitator, helper, and resource provider by creating different situation, encouraging, orientating, inspiring, using Information Communication Technology (ICT) and using multimodality in the classroom.
\end{abstract}

Keywords: learner autonomy, self directed learner, self directed learning

\section{Introduction}

Self Directed Learning is any form of study in which learner individually takes initiation and responsibility of learning. Smith (1982) defines that SDL refers to "individual's ability to control his/ her learning plan/schedule and other learning-related factors" (as cited in Suc and Duo 2010, p.156). SDL engages learners in self-motivation, self-consciousness, self-controlled, self-dependent and active in their learning. The learners set the goals, plan and manage the materials for their own learning. Merriam (2001) argues that "self-directed learning goals should have the development of the learner capacity to be self-directed, fostering of transformational learning and the promotion of emancipatory learning and social action" (p.9). It means, self directed (SD) learners' goals should have self responsible, generalisable of acquired knowledge from one situation to another and make free to learn without any hindrance and disturbance.

SDL is a process of learning in which individuals take the initiative, with or without help of others, finding their learning needs, formulating learning goals, identifying materials and resources for learning, choosing and implementing appropriate learning strategies. In SDL, the learners self initiate for learning, 
take active participation, and learn through self efforts as well as ask support from others if there is need. According to Nunan and Lamb (1996), SDL refers to "situations in which learners accept responsibility for all the decisions concerned with learning but does not necessarily undertake the implementation of those decision"(p. 156). It means, SD learners take all the responsibilities and decisions of own learning but difficult to fulfill all these although SDL helps learners to develop competencies, real-world experiences and familiarity with the subject matter and facing challenges while learning.

Noland and Skidmore (2011 list the three aspects of SDL "the goals, the process, and the learner" (p.4). It suggests, SDL goals should be self-determined or learners' need based, the process should help to fulfill the goals and according to goals. The learners have to manage and arrange the resources. They are the focal point so they should be self-motivated to be successful learners. SDL is constituted by interest, commitment, understanding and practice of the learners. So, Eva and Regehr (2006) define self directed learning is "a claim of self-regulation" (p. 34). The goal of SDL is to help learners to develop autonomy in the learning process. Simply, autonomous learners refer to the learners' ability to do work independently without other's direction. Holec (1981) defines learner autonomy as "the ability to take charge of one's learning"(as cited in Little 1991 p. 1) which means learners' hold the responsibility of one's learning. The learners take all possible advantages and limitations self. It suggests learner autonomy means determining the objectives, defining the contents and progressions, selecting methods and techniques to be used, monitoring the procedure of learning and evaluating what has been learnt. The autonomy itself is relative term because we cannot say you are totally dependent learner and independent learner but it is in continuum as Nunan writes (1997) "the degree of learner of autonomy" and "autonomy is not an absolute concept" (p.13).

An SD learner is one who takes the initiative and the responsibility for what occurs. The individual learner selects, manages, and assesses own learning activities which can be pursued at any time, in any place, through any means. Nunan (2003) argues "Learners who are able to play the kind of active role in their own learning is self directed learners" (p.194). Learners self set the direction which way I have to go, set the aims and objectives for what I am going to, set the methods and procedures to proceed, manage the recourses and monitor the process. Abadi, Jahandar, Khodabandehlou and Seyedi (2012), the key characteristics of SD learners are:

the learner who can take responsibility for learning, an ability to define one's own objectives, awareness of how to use language materials effectively, careful organization of time for learning, and active development of learning strategies (p.3).

SDL is one of the most important concepts of learning. There is no debate regarding the advantages and benefits of SDL. But problems like low degree of students proficiency and knowledge, low achievement in expected outcome, increasing dependency upon teachers, lack of self-confident, passive in leaning and receiving rather than constructing own knowledge suggest learners' due attention of SDL is there. So, the purposes of this study were to explore the teachers' and students' perspectives on SDL for learner autonomy and analyze the teachers' roles to engage students in SDL. This study was also expected to identify difficulties and challenges in SDL to develop autonomy in learning. The prime focus was also 
given on adult education; adult education is in that sense, to be self directed and autonomous, learners should have intrinsic motivation, self-concept, needs and experience. The research will be very helpful to understand about SDL and regarding the future research on the related issues and will be significant to all the stakeholders like teachers, students, researchers, etc.

\section{Review of Literature}

SDL can be described as self-initiated, personal and intentional learning. It involves establishing personal goals, utilizing various resources and becoming personally responsible to learn. According to Hiemstra, (1994), Knowles, North American scholar popularized with andragogy and corresponding with adult instructional processes his work published in (1975) "Self-directed Learning" which provided foundational definitions and assumptions. The first attempt to better understand learning-oriented individuals was made by Tough, A Canadian researcher, his dissertation effort to analyze self-directed teaching activities and subsequent research with additional subjects resulted in a book, 'The Adult's Learning Projects' (1979).

Chee, Divaharan, Tan and Mun (2011) share, after the popularity of Knowles's Andragogy, questions were raised whether the concept of Knowles really unique to the adults or not. In 1987, an 'Establishment of an annual International Symposium on Self-Directed Learning' by Long and his colleagues completed this historical picture. The Symposia have spawned many publications, research projects and theory building efforts by researchers throughout the world. A well-known research by Grow (1991, 1994) 'Staged Self-Directed Learning Model' (SSDL), the matrix presented in this model enables learners to identify their stage of readiness for SDL. Hanson (1996) argued that the characteristics of an adult learner were also found amongst children like adults, children could possess intrinsic motivation to learn, if the problem was of interest to the child, he or she would make attempts to address the need for knowledge in order to solve the problem.

As with the development of many new ideas, SDL has created some confusion in that many related concepts are often used interchangeably or in similar ways. Hiemstra, (1994) includes SDL with self-planned learning, learning projects, self-education, self-teaching, autonomous learning, autodidaxy, independent study and open learning. Though, they are terminologically differing but subtly they are interrelating or corresponding with SDL. So, SDL is development of knowledge and skill in which an individual does efforts by his or her own attempts using any method in any time. SDL does not need formal classroom, formal examination, teachers, group and grades but it does not mean it avoids formal setting.

SDL is obviously based on adult learning theory or andragogy. In simple word, adult is a period of optimum mental functioning when the individual's intellectual, emotional, and social capabilities are at their peak to meet the demands of career. Knowles (1980) defines adult as "fully developed, mature and grownup" (p.24). It means the person who is physically, psychologically, instinctually and socially developed. The persons who have ability to reproduce, develop self concept, and seek roles and responsibility, are adult. Merriam (2001) adult has "the ability to recall, to process information, and to problem solve" (p.4). So, adult can solve the problems themselves, they have the capacity to recall the previous ones, they have 
the ideas to process the information and to solve problems. Adult students have potential possibilities for the learning, they have experiences with world and they have consciousness to learn which make them possible to develop one's abilities more successfully and systematically.

Andragogy is based on adult education. Knowles defines andragogy as "the art and science of helping adults learn," and contrasted with pedagogy, "the art and science of helping children learn" (1980, p. 43). Andragogy becomes a better point for those who are trying to define the field of adult education as separate from other areas of education. From above definition, andragogy is art or science of adult teaching; it deals with the adults. Davenport and Davenport (1985) say andragogy has been classified "as a theory of adult education, theory of adult learning, theory of technology of adult learning, method of adult education, technique of adult education, and a set of assumptions." (as cited in Merriam 2001, p. 5). It suggests andragogy itself is cover term which covers different theory, method and technique so it remains as the most learner-centered of all patterns of adult educational programming.

SDL is directly linked with adult learning theory. At least adult learners are conscious of SD and autonomy. The teachers can play the role of facilitator rather than presenter of content. SD learners can exercise of independence in learning, they can make goals and decide what is worthwhile learning as well as how to approach there. So adults have reason why they need to learn, how it will benefit them and they have earlier experience too which adults want to use what they knew and to be approved for having that knowledge. Adults want to develop self-identity and self-determinant from their experiences. SD learners have their own orientation to learn, readiness to learn which can use real-life situation or problem orientation. Adult learners are self and intrinsically motivated and give importance to internal priorities than external motivators. That's why, SDL or SD learners are based on adult learning theory which is technically called andragogy.

Autonomy simply denotes a significant measure of independence from the control of others or learners' degree of freedom. Little (1991) stresses "Autonomy is a capacity for detachment, critical reflection, decision-making, and independent action" (p. 4). It implies that the learner has the freedom to plan and control his own learning by choosing what, when and how to learn in compliance with their own needs, interests and abilities. Boyadzhieva (2016) argues "learner autonomy refers to individuals psychological capacity to explore their own learning abilities, capacity to take charge of the decision making concerning their learning, intrinsically motivated and freedom of choice"(p.37). So, on the basis of above definition, learner autonomy is the ability of a learner to understand and manage learning processes responsibly and effectively.

The idea of autonomy has grown with various forms of practice including individual learning, self-instruction, self-access, etc. There are no uniformities in its definitions; it differs from one context to another. Dang (2012) states:

The psychological perspective values the personal attributes of the learners; the technical perspective values attributes in the learning environment; the socio-cultural perspective emphasizes the interactions between learners and their environment; and the political-critical perspective focuses 
on learners' access, control, power and ideology in their community (p. 53).

So, we recognize that autonomy is multidimensional and takes many different forms according to person, setting, and multiple contexts. It has been brought into language teaching through psychological, cultural, social and different fields of philosophy. Benson (2011) defines learner autonomy, "as remarkable degree of consensus around the idea that autonomy involves learners taking more control over their learning" (p.16). It is moving from teacher dependency to autonomy. The learners control of own learning in a remarkable degree of continuum.

Eneau (2008) argues autonomy is not merely the ability to direct one's own learning; it takes into account emotional, intellectual, and moral dimensions. It reveals an autonomous learner manages his or her aptitude for own learning and an ability to make judgments in the use of appropriate strategies to learn. The learners can develop autonomy engaging in discussion with others, applying the previous experiences and knowledge creating knowledge from interaction with others. So to construct one's autonomy, it is necessary to learn from oneself, from others and from the resources.

LA is defined as learners' self-initiation and self-regulation. To foster LA, different styles and strategies or approaches are incorporated. Benson (2001) classifies six approaches to develop LA viz resource-based, technology-based, curriculum-based, teacher-based, classroom-based and learner-based. Same as Lo (2010) adds LA has been increasingly promoted, more teachers are aware of shifting their roles from decision-makers to facilitators. The different learner-centered approaches encourage learners to actively participate in every aspect of their learning, including setting goals, selecting materials and strategy and assessing outcomes. Lo (2010) also emphasizes portfolios to promote autonomous language learning because process of portfolio includes self-reflection, self-direction and self-evaluation embedded for promote autonomous learning.

Abdullah, Koren, Muniapan, Parasuraman and Rathakrishnan (2008) conducted research on Adult Participation in Self-Directed Learning Programs in Malaysia was done to explain the different concepts related to SDL. The various concepts regarding adult participation such as autonomous and SD, life experiences and knowledge, goal-oriented, relevancy-oriented, practical and social contact were explained along with its barriers like situational barriers, dispositional barriers which create non-participation in SDL. So, the research outlines concepts why adult learners are engaged in SDL and what are the barriers for not participants in SDL. The research carried by Agung, Lestari and Widjajakusumah (2009) found the positive perceptions and practices of SDL. The students who have positive perception toward student centered learning had a better tendency and practiced student-centered behaviors like self motivation, self management, self readiness, interaction and self assessment. It also suggests the students' areas of residence are dominant factors which influence the student-centered behavior but gender, age and year of entry do not seem to affect the student-centered behavior.

The research of Ahmada and Majidb (2010) found that cultural factors need to be taken into account in the classroom, it is important for the teacher/instructor to understand that cultural factors because that affect classroom interaction strategies. Students learn many styles and strategies from the teachers and friends so the teachers should address the students' diversity to promote them to be autonomy. 
Du's research carried out in (2013) on the topic Student Perspectives of Self-Directed Language Learning: Implications for Teaching and Research outlines that the students are derived from several benefits such as exposure to news texts, an improvement in meta-cognitive ability, higher motivation, improved SDL abilities, skills to prioritize tasks, independently locate resources, read strategically and critically selfappraise. The research also point out the great roles of teacher facilitating the students in learning from students' views.

A research conducted by Khatri (2012) on Self Directed Learning for Teachers' Professional Development which explored the secondary level teachers' awareness of SDL and SDL strategies practiced for teachers' professional development. The finding shows only fifty percent teachers of secondary level English teachers are aware of SDL for teachers' professional development. It means, large number of teachers are still unaware of own career development even they avoid basic activities like self-monitoring, action research, journal writing, analyzing critical incidents, etc. Dhakal (2017) suggests group interaction, presentation, role play, simulation and storytelling help students to develop autonomy in speaking skill. SDL helps learners to be autonomy in all skills with sound knowledge and skills of subject matter.

A single teacher cannot teach all the students individually in the classroom so students should develop a degree of autonomy. SDL can be the best method to develop LA and that is proved by the different research conducted in different counties and contexts. The reviewed empirical literatures have shown the great importance of SDL to develop LA. The reviewed research shows the positive perception toward SDL and it should be encouraged. The different roles of teachers and barriers are also pointed but these all are from the teachers' point of views. So it was conducted to pinpoint the perceptions of both; teachers' and students' point of view along with challenges and difficulties. This research has shown the roles and responsibilities of teachers in context of campus level education.

\section{Methodology}

The present study was based on qualitative research design. Qualitative research is an approach that seeks to make sense of social phenomena as they occur in natural settings. For this study, the populations were campus level English teachers and students in Kaski district. Five English teachers and three groups of students were the sample of this study. Each group contains five students. The purposive non-random sampling procedure was used to select the informants to fulfill the objectives of this study. The primary data was collected from five English teachers and three groups of students.

The interview and focused group discussion (FGD) tools were used for this study. For that, semistructured questions for interview and semi-structured guidelines for FGD were designed. In order to collect data, the first of all, the researcher informed the teachers and students and met them. Teachers were met individually in different time but students were met in college. After that, with building rapport with teachers and students, the researcher explained the purposes of the study then scheduled the time for interview and took the interview. For the FGD, first researcher formed the groups and shared few instructions. The FGD was done in three different days on the basis of students' convenient of time and date. Both, interview and FGD were recorded by a mobile phone. Then, the researcher transcribed all the 
recorded information into written form highlighting the catchy ideas. And this information was analyzed and interpreted using interpretative and analytical procedure.

The researcher used oral consent to the respondents without using any written form and letter. Respondents were insured for maintaining privacy, not misusing the data for other purposes and anonymity of participants by the researcher. The researcher has respected all participants' ideas, did justice to all, excluded the irrelevant information and used unbiased language appropriate for audiences of the research. And dew attention is given on honesty, accuracy, truthfulness and credit for ownership to researcher, participants and advisers.

\section{Results and Discussion}

The collected data from the respondents were analyzed and interpreted under the following quotes from them to illustrate the main themes which were developed.

\section{Perceptions of SDL}

The finding shows that campus level teachers and students have reached certain level of SDL understanding and positiveness. SDL is a learner-centered activity in which learners learn themselves by doing their own activities. Grow (1991) assumes SD is creation of situations in the classroom to direct one subject or one dependent learner to another and degree of teacher talking should minimize. The informants add, "SDL is new approach and learners' autonomy itself in teaching learning context in which teacher creates the situations and students learn themselves where teachers' roles are minimized and students' are maximized".

It argues SDL is a new approach in Nepalese context for teaching and learning language which makes learners to learn doing themselves. The roles of teachers are facilitative and creating the learning situation in the classroom. So, teachers' careful nurture should be there to make students' attention on the subject matter. SDL is for developing autonomy by doing own efforts wherever that can be in the classroom and outside the classroom, individual or collective but learners should be responsible and active in pair, group or whole class.

Eneau (2008) argues SDL is not only directing own learning but the ability to use appropriate strategies in learning but self direction and self motivation is first one. To assist it teachers argue, "It is a way of motivating students for autonomy where learners develop their skills and knowledge by using own efforts and strategies". The learners themselves try to search, find out new things with the help of teacher or without, in that way, they develop insight in learning. SD learners are those learners who have the capacity to drive self in learning. In another word, SD learners should have internal desire or motivation to learn. Motivation motivates them to learn so it is internal drive as well. A teacher compares SDL with motivation saying, "SDL is a pushing factor". It means that SDL is such a drive which motivates learners for learning. So, the concept of SDL can be compared with teachers because they are assumed as the pushing factors to motivate the learners. 


\section{SDL Activities}

In the perceptions of informants, there are different activities which make learners engaged in SDL for LA. The use of SDL activities differ from one student to another obviously because of their different social, psychological and cognitive nature or background. Balçıkanlı (2010) states "Because of differences, involving students in the decisions such as individual/pair group work, use of materials, type of class activities and type of homework activities provides them with choice of different approaches and understandings to foster learner autonomy" (p. 93). As a whole, the activities such as using libraries and using internet for searching materials, exercising to find out the answer of questions themselves are the SDL activities. The interviewees suggest, "This is the era of science and technology and mass media. The students can consult needy materials using mass media such as You Tube, Google, Wikipedia, etc and discuss in group on different issues and topics". This excerpt also proves the activities as searching mass media, discussing in group about the learning areas make learners self directedness. Mass Media also makes learners active and updated with new innovations and changes.

One group strongly suggests to develop autonomy in learning, "We read authentic books and foreigners written, attend different seminars and conferences which help us to generate new ideas and explore our originality and potentiality, study making schedule of each days, etc". These are the self involvement activities which make students self- involved. So we can conclude, when the learners psychologically ready for learning, they realize learning is their own responsibility, they develop their sense of responsibility in learning and do following teachers' path and guidelines, these activities make learners self directedness. The habit of library reading, writing diary or developing self-portfolio, habit of readings further materials than just reading own classroom contents like readings newspapers, research papers and articles, creative works and literary works also help learners for SD.

In the work of Little (2003) shares, "In my own classrooms, I work hard at moving learners along a continuum from total dependence on the teacher to autonomy. I incorporate a series of steps into the educational process which are more content oriented to learning processes". A teacher follows the same process as Little:

Yes I do, while teaching story, I provide some of the lines of the story by picking from different paragraphs and ask them to identify. It is no necessary to say read this story but those lines motivate them to read story where the lines remain.

This is an absolutely delightful way to motivate students in SDL. Such kind of activities helps learners to be curious and habit of inquiry to find out. The students read the whole story without feeling of insistence directly. Besides this, students learn different reading skill such as scanning skill, skimming skill, comprehension skill, etc.

\section{Difficulties and Challenges}

SDL is based on adult learning. Adult learning deals with andragogy. So it is applicable only to college level students. Because of different elements like lack of sufficient number of colleges to enroll the students, overcrowded number of students in a class, lack of resources, no access of mass media, teachers' 
time and students' perception create the difficulties in implementing SDL strategies. Leach (2000) points different factors which are responsible while implementing and challenging SDL strategies viz context, domain of knowledge and level of learning, socialization, confidence, motivation, time, resources and age. An interviewee says, "There are so many challenges as student numbers are very high, students' individual differences, and lack of accessibility of resources. So, it is easy to say but difficult to implement”. The great problem in Nepalese context is overcrowded number of students. Because of high number of students in a class, it is very difficult to deal individually and if teachers' guidance and support do not provide properly, we cannot imagine better achievement and LA. Nepal is a multicultural, multilingual, multiracial and geographically diversified country so the students come from different educational, economical, religious, language and social background which also create the difficulty in higher level too.

Most of the informants' state that the challenges also stand because "Lack of sufficient time we cannot create all situations within 45 minutes and no inspiration from administration". Applying students' centered method or activities itself is time-consuming. The teachers also should do more preparations and practices rather than traditional teaching. But according to informant, there is no such situation because of unavailability of proper resources, lack of sufficient time and any inspiration or encouragement. Doing all the students' centered activities within 45 minutes is also very difficult. And there is lack of inspiration because they grew in such theoretical and traditional scenarios of teaching and learning. But those teachers who are aware of communicative approach, who advocate students centered methods; they should start to create the situation whatever environment they grew. A teacher suggests "Making students self directed itself is challenging. They themselves are unaware about their job and they love and enjoy when teacher provides them complete note". This excerpt argues, students themselves are not interested to engage in SDL. The main challenge faced by the teacher is making aware about SDL and learning is their own duties. Students are not realizing that we should be responsible for our own learning.

Leach (2000) argues, to be the students SD, their existing knowledge of the subject, and the level at which they were learning, made to the amount of control they would want, or be able to take, over their learning are the most. But informants stress "Students want to provide readymade note from the teacher, readymade note entertain them very much, notes are in questions answer, questions are likely to be asked in the exam and students' preferences in capsule note" have created problems in applying SDL activities. Students don't want to spend much time for studying themselves. Learners should be more responsible in their learning but they seem irresistible and dependent to the teacher. They expect the complete note from the teachers that would be asked in exam that suggests students are exam oriented or pass and fail oriented rather than generating own learning. It shows students are patience receiver rather than exploring their own talent.

It was found almost all teachers have same view toward students, not for all students but most of the students have false ideology that is whatever teacher says that is correct and authentic whether that is correct or not that which hinders for developing own responsibilities and autonomy. When the students satisfy from what they get from the teachers and think enough, their further attempt to learn is decline. But as teachers, students also blame teachers, "Because of teacher's rushing time table or schedule timetable 
for teaching in different colleges and also tedious feelings toward applying SDL activities have created the barriers for applying SDL strategies for students' autonomy". This argument suggests, teachers also need to change according to time and needs. The problems and difficulties lay in the students, teachers and administration, unless these stockholders become aware, such new concept will not be entertained.

\section{Teachers' Roles}

Learning is not a single process but it's a joint process among students, teachers, parents, administration, society and many more. To develop the autonomy in learning, students should follow the directions and guidance of the seniors, teachers and other experts. Teachers should provide full exposure, supports and they should use student centered activities, strategies and methods. Teacher roles are facilitator and resourceful person rather than only content deliverer and teacher should create the situation in the classroom and let students to do work. Use of science and technology and mass media can make the students active and self involvement. Besides this, teacher should manage modern libraries, virtual libraries, self access centers, etc which help students to search and identify the needs. As far as possible, teachers and students relation should be sound and there should be cooperation, collaboration between teachers and students and among students too.

Teachers roles should make students to explore their own knowledge, generate own knowledge and exploit the available resources and facilities for own learning. Teachers should help students to be aware of their own talent and should explore. A teacher claims, "Teachers should not confine students only inside the classroom but let students go outside and be always active, eager and quest in every step for learning". It suggests teachers should be shifted from traditional and obsolesce teacher-centered method to students centered methods. Along with teachers' roles, the administration also should play crucial roles making access of libraries, books, internet facilities, inspirations and motivations to the teachers and students. The administration should maintain the school areas impressive and attractive with sound environment.

\section{Conclusion and Implications}

The study was mainly concerned to find out the teachers' and learners' perceptions about SDL, SDL activities, challenges and the teachers' roles to make LA. The respondents have positive perceptions regarding the SDL helps learners to be autonomy. It claims SDL is a pushing factor or drive which makes learners self responsible about own learning and makes learners conscious about learning is their own duties. So SDL is necessary learning strategy for better and meaningful educational achievement. SDL is not only learning individually or learning in isolation but it is learning collaboratively and collectively too. It means, even a learner can learn in pair, in group, or in whole class but he/she should self work, active and self responsible.

SD learners learn how to learn and take challenge to learn using SDL activities like self study, group study, library study, participation in seminars and conferences, use of ICT and mass media. This research also outlines institutional and students' ideological barriers Teachers' roles are inevitable to overcome from these barriers or challenges by motivating the students, being facilitator and resourceful person, situation creator and guiding learners individually as well as collectively. Based on the above findings, this study 
may have a few implications for teachers and students. First of all, in order to help students develop LA, teachers also need to identify the change of teachers' role in teaching learning process. Teachers encourage and give students the skills and learning strategies to learn on their own ways. Overall theme of the study is to develop LA so learners need to use SDL styles and strategies for better learning and achievement.

In conclusion, the informants are no doubt of in favor of SDL for making autonomous learners but there are so many challenges in implementation. Students and teachers are facing difficulties and problems in it but have been practicing SDL activities or strategies for developing autonomy. However, all informants are supported the SDL activities help to develop LA. The researcher believes that this study will contribute for developing LA and in improving results.

\section{References}

Abadi, R. M. D., Jahandar, S., Khodabandehlou M. \& Seyedi G. (2012). The impact of self-directed learning strategies on reading comprehension. International Journal of Scientific \& Engineering Research, 3 (7). Retrieved from: http://www.ijser.org

Abdullah, M. M. B., Koren, S. F., Muniapan, B., Parasuraman, B. \& Rathakrishnan B. (2008). Adult participation in self-directed learning programs. International Education Studies, 1 (3). Retrieved from: www.ccsenet.org/journal.html

Ahmada, B. E. \& Majidb, F. A. (2010). Self-directed learning and culture: A study on malay adult learners. International Conference on Learner Diversity, 7(C) 2542-63. DOI:10.1016/j.sbspro.2010.10.03

Balçıkanlı, C. (2010). Learner autonomy in language learning: Student teachers' beliefs. Australian Journal of Teacher Education, 35(1). Retrieved from: http://ro.ecu.edu.au/ajte/vol35/iss1/8

Benson, P. (2001). Teaching and researching autonomy in language learning. UK, Harlow: Longman.

Boyadzhieva, E. (2016). Learner-centered teaching and learner autonomy. International Conference on Teaching and Learning English as an Additional Language, GlobELT 232 (35). DOI: 10.1016/j. sbspro.2016.10.008

Chee, T. S., Divaharan, S., Tan, L. \& Mun, C. H. (2011). Self-directed learning with ICT: Theory, practice and assessment. Ministry of Education, Singapore.

Dang, T. T. (2012). Learner autonomy: A synthesis of theory and practice. The Internet Journal of Language, Culture and Society, (35), 52-67. Retrieved from: http://www.educ.utas.edu.au/users/tle/ JOURNAL/issues/2012/35-08.pdf

Dhakal, N. P. (2017). Autonomous learning activities of the students for developing their speaking skill. An unpublished thesis of Tribhuvan University, Nepal.

Du, F. (2013). Student perspectives of self-directed language learning: Implications for teaching and research. International Journal for the Scholarship of Teaching and Learning, 7 (2). Retrieved from: https://doi.org/10.20429/ijsotl.2013.070224

Eneau, J., (May 2008). From autonomy to reciprocity, or vice versa? French personlism's contribution to a new perspective on self-directed learning. Adult Education Quarterly, 58 (3), 229-248. DOI: $10.1177 / 0741713608314135$ 
Grow, G. O. (1991). Teaching learners to be self-directed. Adult Education Quarterly ,41 (3) 125-149. Hanson, A. (1996). 'The search for separate theories of adult learning: does anyone really need andragogy?' in Edwards, R., Hanson, A., \& Raggatt, P. (Eds.) Boundaries of adult learning. Nesw York, Routledge.

Hiemstra, R. (1994). Self-directed learning. In T. Husen \& T. N. Postlethwaite (Eds.), The International Encyclopedia of Education (2nd ed.). Oxford: Pergamon Press. Retrieved from: http://home.twcny. rr.com/hiemstra/sdlhdbk.html

Khatri, A. B. (2012). Self-directed learning for teachers' professional development. An unpublished thesis of Tribhuvan University, Nepal.

Knowles, M. S. (1980). The modern practice of adult education: From pedagogy to andragogy. Cambridge, The Adult Education Company.

Leach, L. (2000). Self-directed learning: Theory and practice. An unpublished Doctoral thesis of University of Technology, Sydney.

Lestari, E. and Widjajakusumah, D. (2009). Students' self-directed learning readiness, perception toward student-centered learning and predisposition towards student- centered ehavior. South East Asian Journal of Medical Education, 3 (1).

Little, D. (1991). Learner autonomy: Definitions, issues and problems. Dublin, Authentik.

Lo, Y. F. (2010). Implementing reflective portfolios for promoting autonomous learning among EFL college students in Taiwan. Language Teaching Research, 14, (1). DOI: 10.1177/1362168809346509

Merriam, S. B. (2001). Andragogy and self-directed learning: pillars of adult learning theory. New Direction for Auld and Continuing Education, 89.

Noland B. \& Skidmore J. L. (2011). Adult learner success strategies. West Virginia Higher Education Policy Commission and West Virginia Council for Community and Technical College Education.

Nunan, D. \& Lamb, C. (1996). The self directed teacher managing the learning process. UK, Cambridge university press.

Nunan, D. (1997). Designing and adapting materials to encourage learner autonomy. In P. Benson \& P. Voller (Eds.), Autonomy and Independence in Language Learning, 192-203.

Nunan, D. (2003). Learner training and autonomy: A Nine steps to learner autonomy. Collaborative Language Learning and Teaching. A Symposium 2003, 193-204. Retrieved from www.andrasprak. su.se/polopoly_fs/1.84007.../menu/.../2003_11_Nunan_eng.pdf

Regehr G. \& Eva K. (2006). Self-assessment, Self-direction, and the Self-regulating Professional. Clinical Orthopedics and related Research (449), 34-38. DOI: 10.1097/01.blo.0000224027.85732.b2

$\mathrm{Su}, \mathrm{M} . \mathrm{M} \& \mathrm{Du}, \mathrm{P} .(2010)$. EFL learners' language learning strategy use as a predictor for self-directed learning readiness, The Journal of Asia TEFL, 7(2), 153-176.

Luk Gharti, who graduated from the University Campus, Kirtipur, currently, is teaching at Janapriya Secondary School as a Secondary Level English teacher in Syangja. 